\title{
Ecological Footprint and Decoupling in the Sustainable Development of a Region
}

\author{
Larisa Shut'ko' ${ }^{1}$ Lyudmila Samorodova, ${ }^{1, *}$, and Anastas Ivanov ${ }^{2}$ \\ ${ }^{1}$ T.F. Gorbachev Kuzbass State Technical University, Department of Economics, 28, Vesennyaya, \\ Kemerovo, 650000 \\ ${ }^{2}$ T. Kableshkov University of Transport, Department of Theoretical, Fluid, Applied and Structural \\ Mechanics, 158, Geo Milev, Sofia, Bulgaria, 1574
}

\begin{abstract}
The purpose of the study is to examine the issues of assessing the anthropogenic impact on the ecosystem and sustainable development of a region using the example of Kuzbass. The subject of the study is to substantiate the need to improve the measurements of sustainable development of the regional economy from the point of view of calculating the "ecological and carbon footprints" of Kuzbass, identifying the effect of decoupling the negative impact on the environment and resource consumption in the process of economic activity of coal mining enterprises. The following tasks are solved: 1 . The role of the environmental factor in ensuring sustainability of the resource-producing region development is shown. 2. The possibilities of using the "ecological footprint" and the "carbon footprint" as indicators of sustainable development of Kuzbass are discovered. 3. The role of mining enterprises in the formation of the "carbon footprint" in Kuzbass was revealed. 4. The calculation was carried out and the effect of decoupling in the coal mining of Kuzbass in 2013-2017 was revealed. 5. The necessity of including the indicators of "ecological footprint", "carbon footprint" and the effect of decoupling in the coal mining in the system for assessing sustainable development of the mining region in accordance with the UN sustainable development goals (hereinafter - the UN SDGs) is justified. 5. It is argued that it is necessary to expand voluntary greening of enterprises in the coal mining of Kuzbass. Research methods are elements of system and integrated approaches, comparative analysis methods.
\end{abstract}

\section{Introduction}

Solving the problems of sustainable development and adopting the principles of the sustainable development concept (Stockholm Conference, 1972) increase the role of system approach to the study of the socio-economic development of regions and countries as a three-dimensional model, the main structural elements of which are economic, social, and environmental spheres of life. The dominant source of life-supporting resources of the territories is the environment. Sustainable development of a region as a socio-ecological-

\footnotetext{
*Corresponding author: luda-sll@yandex.ru
} 
economic system is ensured by integrity, emergence, and the ability to self-develop, i.e. properties of a system object. The role of assessing sustainable development on the basis of the development and improvement of a whole range of aggregated indicators is growing. In modern society, one of the debated global topics is the economic growth of national (regional) economies without increasing resource consumption and waste generation based on the UN Sustainable Development Program.

The measurement of sustainable development is aimed at expanding the voluntary greening of countries and businesses. For the resource-producing region, the calculation of the "ecological footprint" and "carbon footprint" indicators is of particular importance. The "carbon footprint" is considered as part of the "ecological footprint" of enterprises and regions. The authors support the position of scientists who consider it possible to reduce the anthropogenic load on the environment in the context of the growth of the gross product of a country and a region when the decoupling effect in the extractive industry, including in the coal mining and coal processing sectors, is revealed.

In the framework of this study, the characteristic of "ecological and carbon footprints" as indicators of the sustainable development of Kuzbass is given, the decoupling effect in the coal mining sector of Kuzbass is calculated.

\section{Results and discussion}

Ensuring future sustainable development is possible on the basis of a compromise between economic growth and environmental conservation, which is the subject of research by foreign scientists [1-3]. Sustainable environmental development means the implementation of the UN Sustainable Development Program goals at the level of countries, regions and enterprises (UN SDGs 8; 13 and 15) related to "sustainable economic growth and employment", "responsible consumption and production", and conservation of the biosphere [4]. To assess sustainable development of the economy of a country, region, taking into account the environmental factor, aggregate (integral) indicators are widely used: Nordhaus and Tobin Sustainable Welfare Index [5], Environmental Sustainability Index, Environmental Development Index, Sustainable Economic Welfare Index, General Progress Indicator, HDI (Human Development Index), the Living Planet Index, as well as the system of eco-economic accounting, including "green accounts, environmentally friendly internal product [6], adjusted net savings or "true savings", "ecological footprint" by W. Ries (1992), M. Wackernagel (1994), "environmental debt", "carbon footprint" by D. Stiglitz, A. Sen, J.-P. Fitoussi (2008) [7]. For example, foreign researchers evaluate the results of the "green economy" development and "carbon footprint" of the Chinese provinces [8], as well as Italy [9] and other countries and regions [10]. The following Russian scientists contributed to the study of "ecological footprint" as an indicator of sustainable development: N.E. Buletova, A.I. Tatarkin, G.A. Gershanok. N.V. Kostin, A.G. Rosenberg, G.S. Rosenberg, G.R. Khasaev, D.S. Ermakov, D.A. Slavinsky, S.A. Chernikova, O.S. Sausheva.

The ecological footprint calculation allows determining whether the economy of a region matches the capacity of its natural ecosystems - the "ecological capacity of a territory". "The bio-capacity of a region is biologically productive land and water areas that can provide ecosystem services to humans, including provision of bio-resources (food or timber), placement of infrastructure facilities and absorption of waste, including carbon dioxide generated during the burning of fossil fuels" [4]. "Eco-capacity of a territory" can be considered as "capacity of the ecosystem of a territory to generate $\mathrm{O}_{2}$ and absorb $\mathrm{CO}_{2}$ resulting from anthropogenic activities". According to the World Wide Fund for Nature in Russia, the average per capita indicator of bio-capacity, from 1991 to 2016, ranged from 6.5 gga to 7.0 gga. The total bio-capacity of Russia exceeds the ecological footprint by 
$35 \%$, but this is achieved due to the large territory of the country and low population density [11]. The Siberian Federal District and the Far Eastern Federal District have the largest share of bio-capacity among the federal districts of the Russian Federation. The North Caucasus Federal District has the smallest share, with the country's lowest environmental footprint. Of the 12 subjects of the Siberian Federal District, $42 \%$ of the total bio-capacity of a region is concentrated in the Krasnoyarsk Territory, the Irkutsk Region is in second place, and the Kemerovo Region is only 11th in terms of bio-capacity. The TransBaikal Territory has the maximum ecological footprint per capita (6.2 gga), the Republic of Altai has the minimum ecological footprint per capita (3.8 gga). Kemerovo region is in 4th place (5.3 gga) [12].

The results of the assessment of "nature intensiveness of the economy of Kuzbass in 2001-2004 (G. E. Mekush) has shown that the development of the Kuzbass mining region economy during the USSR period and for several post-perestroika decades has been generally "anti-environmental nature-intensive". At the same time, traditionally, fuel, energy and metallurgical industries make the largest contribution to environmental pollution and the formation of accumulated environmental damage, but they also create the bulk of the cost of the gross regional product of Kuzbass.

A necessary component of assessing the "ecological footprint" of enterprises and a region is the "carbon footprint of products" indicator and methods for its calculation (foreign and Russian). The scientific interest of foreign researchers in the carbon footprint calculating methods $(\mathrm{CF})$ is due to its "significant role in the ecological footprint (EF). Typically, the share $(\mathrm{CF})$ is about $50 \%$ of the global (EF)", as a rule, (CF) is the only reason for its excess", in (CF in Russia in 2016 is 68\%) [11]. The Report "On the Environmental State and Protection of the Russian Federation in 2018" (according to NFA estimates) reflects that for the period 2014-2017 the total ecological footprint of the constituent entities of the Russian Federation increased by $0.8 \%$, and from 2014 to 2020 an increase of $2.8 \%$ is expected. The overall increase is mainly due to the growth of the carbon footprint for these periods by $1.8 \%$ and $4.1 \%$ respectively, and the footprint of forestry products (by $3.9 \%$ and $8.0 \%$ ).

Reporting on total greenhouse gas emissions $\left(\mathrm{CO}_{2}\right.$, methane, etc.) according to the December Paris Climate Agreement of 2015 ratified by Russia in 2019-2020 should be considered as a universal criterion for the environmental friendliness of companies, affecting their investment attractiveness. Investors' interest in sustainable and low-carbon investments is increasing, but at the same time, divestments (withdrawal of investments) from the sectors of conventional fossil fuels are also increasing. In Russia, the concept of "product carbon footprint" and the technique for its assessment are presented in the National Standard of the Russian Federation GOST R 56276-2014/ISO/TS 14067:2013. This standard is identical to the international document ISO/TS 14067:2013 "Greenhouse gases. Carbon footprint of products. Requirements and guidelines for quantification". The voluntary public provision by enterprises of information on product carbon footprint has a targeted focus, including: to provide transparent (reliable) information to consumers and other users for decision-making; to ensure comparability of products and services on free and open markets. Sustainable development and the greening of business demands increase environmental transparency of all market participants, while along with the state regulation of environmental processes, the role of the voluntary greening of business is growing, which is a global trend.

The relatively low cost of coal and its storing, a good supply of reserves resulting in increased energy security, and growing employment in the coal industry, continue to increase coal production in mining regions, including Kuzbass. The Kuzbass Social and Economic Development Strategy for the Period until 2035 states that the share of Kuzbass in the all-Russian coal production is about $60 \%$. Coal is mined by over 90 enterprises (underground mines and open pits), which employ more than 100 thousand people. The mining and metallurgical sectors dominating in the regional economy account for more 
than $70 \%$ of the total volume of goods produced in the region, $32 \%$ of tax payments to the consolidated budget of the region come from coal miners.

A high level of concentration of industrial enterprises in Kuzbass, including extractive ones determines their high share per unit area in terms of emissions from stationary sources into the air. The area of the region is 95.7 thousand square meters; it means that there are 15.6 tons of pollutants per square kilometer, which is a fairly high level of pollutant emissions for Russia. Most of the electricity consumed in mining, manufacturing and distribution of electricity, gas and water (more than 70\%). Among enterprises generating electricity more than half are thermal power plants. When calculating the Kuzbass carbon footprint, it is necessary to take into account the global trend in considering thermal power plants that use carbon-containing fuel (primarily coal and gas) as the main sources of $\mathrm{CO}_{2}$ emissions. Coal contains more carbon per unit mass than natural gas, and several times less energetically valuable (and environmentally friendly) than hydrogen. In addition, coal-fired power plants are usually less efficient than gas-fired ones; therefore they consume more fuel energy to generate $1 \mathrm{kWh}$ of electricity. All this together leads to the coal-fired TPPs emitting 2-2.5 times more $\mathrm{CO}_{2}$ per one $\mathrm{kWh}$ of electricity generated. A comparative analysis of the volume of pollutant emissions into the air from stationary and mobile sources in the context of the subjects of the Siberian Federal District in 2018, based on the calculation of the total emissions and the share of emissions from mobile sources made by the authors, permitted a number of conclusions.

In 2018, the total emissions of pollutants (including railway transport emissions) in the Siberian Federal District amounted to 6,925.1 thousand tons, which is $8.6 \%$ less than in 2017 and $11.0 \%$ less than in 2010 . Emissions from stationary sources in 2018 amounted to $5,216.8$ thousand tons decreasing by $9.5 \%$ compared with 2017 and by $11.1 \%$ compared with 2010. The maximum indicator of the total volume of pollutant emissions in 2018 was in the Krasnoyarsk Territory (2 618.6 thousand tons), including emissions from mobile sources which amounted to only $11.4 \%$, in Kuzbass - 1619.4 thousand tons and $14.5 \%$, respectively, in the Republic of Tyva -20.7 thousand tons and $81.6 \%$, respectively. The main stationary sources of air pollutants in Kuzbass are extractive enterprises, manufacturing enterprises and electric energy, gas and steam enterprises. (Table 1 is based on the reports on the state of the environment of the Kemerovo region published by the Department of Natural Resources and Ecology of the Kemerovo Region Administration).

Table 1. Emissions of major pollutants from stationary sources, Kuzbass.

\begin{tabular}{|c|c|c|c|c|c|}
\hline \multirow{2}{*}{ Pollutants } & \multicolumn{5}{|c|}{ Emissions, thousand tons } \\
\cline { 2 - 6 } & 2013 & 2014 & 2015 & 2016 & 2017 \\
\hline $\begin{array}{c}\text { Total in the region, } \\
\text { including }\end{array}$ & 1356,297 & 1331,688 & 1344,459 & 1349,484 & 1487,648 \\
\hline Solid & 130,816 & 138,321 & 146,136 & 142,084 & 146,780 \\
\hline $\begin{array}{c}\text { Gaseous and liquid, } \\
\text { including: }\end{array}$ & 1225,481 & 1193,367 & 1198,323 & 1207,400 & 1340,868 \\
\hline sulfur dioxide & 99,041 & 100,862 & 110,908 & 124,928 & 133,541 \\
\hline carbon monoxide & 265,095 & 258,840 & 235,453 & 241,486 & 274,666 \\
\hline $\begin{array}{c}\text { nitrogen oxides (in } \\
\text { terms of NO2) }\end{array}$ & 55,614 & 63,002 & 68,474 & 74,670 & 78,520 \\
\hline $\begin{array}{c}\text { hydrocarbons (without } \\
\text { VOCs) }\end{array}$ & 790,017 & 756,371 & 768,964 & 754,417 & 840,069 \\
\hline $\begin{array}{c}\text { volatile organic } \\
\text { compounds (VOCs) }\end{array}$ & 4,079 & 4,348 & 4492 & 5,696 & 7,253 \\
\hline Other gases & 11,635 & 9,944 & 10,032 & 6,203 & 6,819 \\
\hline
\end{tabular}


An analysis of the data showed that the volume of pollutant emissions from stationary sources in 2014 decreased by $1.9 \%$ compared to 2013. A slight increase in emissions was observed in 2015 and 2016, but in 2017, emissions reached a maximum (1,487.648 thousand tons). The amount of emissions increased by $10.2 \%$ compared to 2016 . In the structure of emissions, the most significant share is the emissions of hydrocarbons (without VOCs) and carbon monoxide. Their share in the total volume of pollutant emissions in 2017 was $68 \%$.

In conditions of intensive coal mining, the transition to sustainable development requires the achievement of decoupling effect. There are absolute decoupling and relative decoupling. In the case of absolute decoupling, an increase in production volumes is accompanied by a decrease in the use of resources and a reduction in the environmental pollution rate. When the production growth rate exceeds the resource use and environmental pollution rates, relative decoupling takes place. Decoupling can act as an indicator of measuring sustainable development of the regional economy in accordance with SDG 8, aimed at improving global resource efficiency and decoupling economic growth from environmental degradation. Coal industry enterprises are one of the main sources of negative impact on the natural environment of Kuzbass, so it is important to find out whether the decoupling effect is manifested in the operation of coal mining enterprises. To do this, we determine the correlation between the coal production growth and the change in indicators of the negative impact of the coal industry on the environment of the region. The indicators of the negative impact of the economic activities of coal enterprises on the region's environment are presented in Table 2. The necessary data for constructing a pair regression model are taken from the official statistical directory "Kuzbass in figures" and the annual reports on the state of the environment of the Kemerovo Region published by the Department of Natural Resources and Ecology of the Kemerovo Region Administration (Table $2)$.

Table 2. Indicators used to identify the decoupling effect in the coal mining of Kuzbass.

\begin{tabular}{|c|c|c|c|c|c|}
\hline Indicators & $\mathbf{2 0 1 3}$ & $\mathbf{2 0 1 4}$ & $\mathbf{2 0 1 5}$ & $\mathbf{2 0 1 6}$ & $\mathbf{2 0 1 7}$ \\
\hline Coal production, million tons & 203,0 & 211,0 & 215,8 & 227,4 & 241,5 \\
\hline $\begin{array}{c}\text { Total pollutant emissions into } \\
\text { the atmosphere, thousand tons }\end{array}$ & 840,853 & 807,057 & 810.597 & 812,178 & 915,068 \\
\hline $\begin{array}{c}\text { Water withdrawal from water } \\
\text { bodies, }\end{array}$ & 348,277 & 331,109 & 323,289 & 321,793 & 326,731 \\
\hline $\begin{array}{c}\text { million cubic meters } \\
\text { Use of fresh water, } \\
\text { total million cubic meters }\end{array}$ & 87,018 & 79,135 & 80,476 & 79,523 & 71,307 \\
\hline $\begin{array}{c}\text { Discharge of sewage, surplus, } \\
\text { mine water into water bodies, } \\
\text { total million cubic meters, of } \\
\text { which: }\end{array}$ & 303,983 & 280,350 & 271,863 & 271,795 & 287,774 \\
\hline- polluted waters, cubic meters & 221,216 & 208.794 & 174,685 & 166,481 & 173,250 \\
\hline \multicolumn{2}{c|}{$\begin{array}{c}\text { as of } \\
\text { Area of disturbed land, ha }\end{array}$} & $\begin{array}{c}\text { as of } \\
5,01.13\end{array}$ & $\begin{array}{c}\text { as of } \\
56,01.14 \\
01.01 .15 \\
53,255\end{array}$ & $\begin{array}{c}\text { as of } \\
01.01 .16 \\
61,226\end{array}$ & $\begin{array}{c}\text { as of } \\
01.01 .17 \\
98,093\end{array}$ \\
\hline
\end{tabular}

To determine the dependence of indicators, we use a one-factor linear regression model. The coal production volume for the period 2013-2017 is taken as an independent variable $X_{t}$, and be environmental indicators will be dependent variables $Y t^{i}$.

The one-factor model is as follows:

$$
Y_{t}{ }^{i}=a X_{t}+b
$$

where $a$ - regression coefficient, $b$ - constant. 
The construction of linear regression is reduced to an assessment of its parameters $a$ and $b$ and their economic interpretation. Parameter $a$ is a regression coefficient and shows the average change in the result when the factor changes by one. Parameter $b$ shows the value of $Y$ at $X=0$. The degree of correlation between the selected indicators is characterized by a linear correlation coefficient $r_{x y}$, which can take on a value from +1 to -1 . A positive value of the correlation coefficient indicates a direct relationship between $X$ and $Y$, and a negative value indicates feedback. By the results of the pair correlation coefficient values, the correlation degree is determined according to Cheddock scale:

$0.1<r_{x y}<0.3-$ correlation is low;

$0.3<r_{x y}<0.5$ - correlation is moderate;

$0.5<r_{x y}<0.7-$ correlation is noticeable;

$0.7<r_{x y}<0.9-$ correlation is high;

$0.9<r_{x y}<1-$ correlation is very high.

The results of the impact of coal production volumes on each pollution type are reflected in the form of the presented one-factor econometric models in Table 3

Table 3. One-factor linear regression models of the coal production impact on environmental performance.

\begin{tabular}{|c|c|c|c|}
\hline Pollutions & Model & $\begin{array}{l}\text { Linear correlation } \\
\text { coefficient } r_{x y}\end{array}$ & Determination coefficient $\boldsymbol{R}^{2}$ \\
\hline $\begin{array}{c}\text { Air } \\
\text { pollutions }\end{array}$ & $\begin{array}{c}Y t^{O B}=2.001 X i \\
\quad+397.372\end{array}$ & $\begin{array}{c}0.659- \\
\text { correlation is noticeable }\end{array}$ & $\begin{array}{l}R^{2}=0.45 \text { - only in } 45.3 \% \text { of } \\
\text { cases changes in coal production } \\
\text { volumes lead to a change in the } \\
\text { volume of total pollutant } \\
\text { emissions into the atmosphere }\end{array}$ \\
\hline $\begin{array}{c}\text { Water } \\
\text { withdrawal }\end{array}$ & $\begin{array}{c}Y t^{3 B}=-0.468 X i \\
\quad+433.076\end{array}$ & $\begin{array}{l}-0.859- \\
\text { correlation is high }\end{array}$ & $\begin{array}{l}R^{2}=0.432-\text { only in } 43.2 \% \\
\text { of cases changes in coal } \\
\text { production volumes lead to a } \\
\text { change in water withdrawal } \\
\text { from water bodies }\end{array}$ \\
\hline $\begin{array}{c}\text { Fresh } \\
\text { water use }\end{array}$ & $\begin{array}{c}Y t^{C B}=-0.3368 \mathrm{Xi} \\
\quad+153.509\end{array}$ & $\begin{array}{l}-0.907- \\
\text { correlation is very high }\end{array}$ & $\begin{array}{c}R^{2}=0.822-\text { only in } 82.2 \% \\
\text { of cases changes in coal } \\
\text { production volumes lead to a } \\
\text { change in the use of fresh water }\end{array}$ \\
\hline $\begin{array}{l}\text { Water } \\
\text { discharge }\end{array}$ & $\begin{aligned} Y t^{C} & =-0.2943 X i \\
& +347.826\end{aligned}$ & $\begin{array}{l}-0.329- \\
\text { correlation is moderate }\end{array}$ & $\begin{array}{l}R^{2}=0.109-\text { only in } 10.9 \% \\
\text { of cases changes in coal } \\
\text { production volumes lead to a } \\
\text { change in the discharge of } \\
\text { sewage, surplus, mine water into } \\
\text { water bodies }\end{array}$ \\
\hline $\begin{array}{l}\text { Waste } \\
\text { water } \\
\text { discharge }\end{array}$ & $\begin{array}{c}Y t^{\mathrm{C} 3}=-1.295 \mathrm{Xi} \\
+473.455\end{array}$ & $\begin{array}{l}-0.796- \\
\text { correlation is high }\end{array}$ & $\begin{array}{l}R^{2}=0.634-\text { only in } 63.4 \% \\
\text { of cases changes in coal } \\
\text { production volumes lead to a } \\
\text { change in the discharge of } \\
\text { polluted water }\end{array}$ \\
\hline $\begin{array}{l}\text { Disturbed } \\
\text { lands }\end{array}$ & $\begin{array}{c}Y t^{H 3}=1.082 X i- \\
172.975\end{array}$ & $\begin{array}{l}0.863 \text { - } \\
\text { correlation is high }\end{array}$ & $\begin{array}{l}R^{2}=0.745-\text { only in } 74.5 \% \\
\text { of cases changes in coal } \\
\text { production volumes lead to a } \\
\text { change in the area of disturbed } \\
\text { land }\end{array}$ \\
\hline
\end{tabular}

Conclusions obtained as a result of the calculations are presented in Table 3

1. Indicators of emissions of pollutants into the atmosphere have a positive close correlation with coal production. The regression equation shows that an increase in coal production of 1 million tons may lead to additional emissions of pollutants into the air in the amount of 2,001 tons. But the total emissions for the study period grew on average at a slower rate compared to the coal production growth rate, so we can suppose the real possibility of achieving the decoupling effect between coal production and air emissions. 
2. All four indicators of water consumption and pollution (see Table 3) have a fairly strong correlation with the increase in coal production. However, the presence of negative values of the correlation coefficients reflects the inverse relationship between the increase in coal production and these indicators. Thus, the decoupling effect in water consumption and pollution is observed in 2013-2017.

3. The obtained positive correlation coefficient between coal production and the area of disturbed lands $r_{x y}=0.863$ shows a stable direct relationship between these indicators. It follows from the regression equation that each additionally mined one million tons of coal leads to an increase in the area of disturbed lands in the amount of 1,082 ha. As a result, the coal mining in Kuzbass is still accompanied by a constant increase in the area of disturbed lands. This trend does not contribute to the formation of conditions for the decoupling effect manifestation. At the same time, areas of disturbed lands are reduced due to reclamation and corresponding rezoning of previously disturbed and mined lands, which is a positive trend. According to the regional coal industry department, as of October 2019, there were 102,000 ha of disturbed lands in the region, of which more than 95,000 ha were affected by mining. According to experts, the estimated cost of reclamation of one hectare of land in the territory of the Kuzbass region is 200,000 rubles. Reclamation works are generally estimated at 19 billion rubles. Therefore, the high cost of reclamation work, their annual growth is a serious reason for the low interest of coal miners in reclamation.

4. The presented calculations on revealing the decoupling effect in the Kuzbass coal mining industry indicate that in 2013-2017 there is a trend in the movement of the coal industry in the region along the path of greening economic activity.

\section{Conclusion}

In modern conditions, it is necessary to reduce the "ecological footprint" of regions and enterprises by reducing the consumption of resources per unit of output.

Increasing voluntary greening of coal mining enterprises, including by calculating the "carbon footprint of production" contributes to the efficiency of the enterprise's environmental risk assessment based on waste accounting and reduction throughout the products' supply chain and improves environmental safety and transparency of coal mining enterprises.

Sustainable economic development of the conventional industry region, where economic growth largely depends on the development of the coal mining industry, should not lead to an increase in anthropogenic impact on the environment as coal production increases, i.e. change indicators characterizing the negative impact on the environment.

Mismatch, discrepancy between economic growth, on the one hand, and resource consumption, environmental impact, on the other hand, i.e. the "decoupling effect" should be considered as one of the indicators of sustainable economic development based on the "green economy" principles.

The results obtained by identifying the "decoupling effect" in the basic industry of the Kemerovo region indicate that in 2013-2017 the movement of the coal industry in the region along the path of greening economic activity is seen, which is a positive trend compared to previous periods of the Kuzbass coal industry development.

\section{References}

1. J. Forrester, Industrial dynamics (Cambridge, M.I.T. Press, 1961) 
2. D. H. Meadows, D. L. Meadows, J. Randers, W. W. Behrens, The Limits to Growth A report for the Club of Rome's Project on the Predicament of Mankind (New York, 1972)

3. P. Ehrlich, A. H. Ehrlich, Electr. Journ. Sust. Dev., 1 (3), 63 (2009)

4. W. Nordhaus, J. Tobin, Is growth obsolete? (Columbia University Press, New York, 1972)

5. J. Stiglitz, A. Sen, J.P. Fitoussi, Report of the Commission on Measuring Economic Indicators and Social Progress (2009)

6. W. Li, Y. Xi, Q. Liu, M. Li, X. Wu, S. Zhu, Ecol. Indic., 112 (Columbia University Press, New York, 2020)

7. I. Nishkov, I. Grigorova, S. Stoev, Proc. of Int. Energy Raw Mat., 21, 45 (2015)

8. L. Samorodova, L. Shut'ko, Yu. Yakunina. O. Lyubimov, P. Kovacs, E3S Web of Conf., 141, 04011 (2019)

9. J. A. Aragon-Correa, A. Marcus, D. Vogel, The Acad. of Man. Ann., 14, 20 (2020)

10. M. King, B. Tarbusch, A. Teitelboim, Eur. Econ. Rev., 119 (2019)

11. D. Zhang P. Du, J. Clean. Prod., 258, 10 (2020)

12. A. Stamm, Sustainability-oriented innovation systems: towards decoupling economic growth from environ-mental pressures? (Bonn, 2009) 